\title{
The Russian Revolution Centennial: New Themes, Scripts and Narratives
}

\author{
Daniel Orlovsky \\ Southern Methodist University \\ dorlovsk@smu.edu \\ Boris Ivanovich Kolonitskii \\ European University in St. Petersburg; St. Petersburg Institute of History, \\ Russian Academy of Sciences \\ boris_i_kol@mail.ru
}

The Russian Revolution Centennial has produced a wave of events, conferences, publications, memorials all aimed at both preserving and shaping memory as well as producing new paradigms, explanations and thoughts about the meaning of it all. The Centennial comes at a time of decreasing interest among scholars in the Revolution as a unique explosion in 1917 as opposed to a longer process embracing the Great War and Civil War. Even with the expanded time frame, sometimes extending even further into the 1920's, the great push in historiography and in graduate student research topics turned into recently published books has focused on the Soviet era, Stalin's regime, and now the post-Stalin decades. In general this description fits the state of scholarly play in the West and Russia, around the globe, in Eastern Europe, and in the independent lands of former Soviet space. That said, however, there remains a serious and dedicated group of researchers on the Revolution whether it be to the 1917, or elongated version. At the same time the afterlife of the Revolution remains a live question. Its enormous impact on the course of global history in the twentieth century and beyond is undeniable. Other revolutions, some derivative, others imitative, Fascism, de-colonialization, War, the Cold War and the color Revolutions of more recent times owe much to the original Russian script. And there is the question of memory, celebration, or avoidance thereof, as we have seen so tellingly in the largely indifferent response of the Putin regime and official Russia to the challenge of the Centennial.

The papers published here are the result of an International Conference on the Epoch of the Russian Revolution, 1914-1922 held in June, 2016 at the 
European University of St. Petersburg. This meeting was one of the ongoing triennial series of international colloquia sponsored by the St. Petersburg Institute of History of the Russian Academy of Sciences, the European University of St. Petersburg, and a leading group of western scholars. In 2016 Southern Methodist University was also a sponsor. The meeting was generously funded by all three institutions, but especially by a generous grant from the Carnegie Corporation of New York and another from RFFI in Russia. The conference brought together approximately thirty scholars from Russia, the West and around the globe for several days of intensive work that resulted in the publication of a volume that included the papers, formal commentaries and the transcripts of the discussions and concluding session. ${ }^{1}$ The penultimate panel (prior to the concluding panel discussion) "General Questions of the History of the Revolution," is here reproduced in translation in the case of the two Russian papers (Kolonitskii and Buldakov) and the formal commentary of Professor Jan Plamper. The essays of Daniel Orlovsky and William G. Rosenberg are provided in their original English form with slight modification.

\section{Acknowledgments}

This publication was made possible in part by a grant from the Carnegie Corporation of New York. The statements made and views expressed are solely the responsibility of the authors. This publication also acknowledges financial support from RFFI, project, "Politicization of the Language of Religion and Sacralization of the Language of Politics during the 'Civil War' Era," No. 17-81-01042.

1 B.I. Kolonitskii and D. Orlovski, Eds., Epokha voin i revoliutsii, 1914-1922: Materialy mezhdunarodnogo kollokviuma, 9-11 iunia 2016 goda. Sankt Peterburg, Nestor-Istoriia, 2017. 